\title{
TJETYPOTIJ]
}

\section{Some Economic Aspects of Western Rangeland Management and Conservation}

\section{MONT H. SAUNDERSON}

As one who has, over the past 50 years, worked professionally on both the enterprise cconomics and the land economics of Western rangelands usage and management, I wish to offer some comments from both viewpoints regarding the management and conservation of this resource.

There are types of rangeland resources where the economics of conservation practically enforces management and good usage. This is particularly true for the mixed prairie grasslands of the northern plains because such lands show the disastrous results of misuse soon enough to permit the rangeland resource to recover with at least reasonable usage. At the other end of the scale are those rangeland types where the resource will not inflict an economic penalty on the enterprise for misusage evident enough or soon enough to avoid eventual disaster for the resource.

illustration of this is the ecologic disaster of the displacement of native bunchgrasses by cheatgrass throughout most of the sagebrush-grass type of the intermountain West.

If all of the Western rangeland types had the same response to overuse and mismanagement (and drouth) as the mixed prairie grasslands of the Western plains, there probably would not be any great need for either range management or land economics. However, that isn't the situation; because of early lack of management information and because in many situations our enterprise economics has been conducive to the "mining" of the resource, we now have a great need for all that management science and education can offer us. And, I believe, the applications of both ranching

The author has served as a Western lands economist and a consultant in Western stock ranch management. His present address is Sun City Center, Florida. enterprise economics and land economics can play an important role in this.

One of the impediments to the applications of modern range science through the planning of the ranching enterprise is the uncertainty as to both the time span and the returns for a program in rangeland rehabilitation and improvement. This is why it is important that the experimental work of range science give as much economic information as possible. Beyond that is the need for public programs, the programs of agencies, for example, to carry some of the cost and the risk of the implementation of change for rehabilitation, and further, to act as educational resources in the application of developments in range science.

The application of work in land economics to range management involves social goals, such as long-range watershed conservation or recreational uses of the resource. Such goals relate largely, though not entirely, to the management of the lands in public ownership. There are also lands in private ownership where rangeland management may have important watershed or recreational values, and such values may not be realizable through the economics of the enterprise. To the fullest extent possible, research in land economics should provide quantitative measures of such values. The expression of social values in monetary terms has, of course, definite limitations. One cannot "put the dollar sign" on the future health, energy, and spiritual welfare of a people.

As a result of my work in the fields of Western stock ranch enterprise economics and Western land economics, I feel that we can be only moderately optimistic concerning the future good use and conservation of the Western rangeland resources. I believe that certain national economic and social trends are inimical to good use and conservation. I further believe that these national trends have a special impact upon the rangeland resources of the arid West, not only because of some inherent characteristics of the resource, but because of certain aspects of the Western stock ranching enterprise.

Here, as I see them, are some of the important basics of the economics of the future development, management, and conservation of the Western rangeland and livestock ranching resources:

1) Throughout our history, our national agricultural economy has been essentially exploitive. This has been the situation because through most of our history we have had a frontier and new lands to develop. This has caused our agricultural economy to work at an extensive level, with little if any concern for resource maintenance. During the past 50 years or more, we have had, additionally, national policies and programs for the stimulation of agricultural production for the assurance of plentiful food supplies. As a consequence of those influences, except for wartime, we have not until very recently had a level of agricultural prices and incomes conducive to the maintenance and renewal of the land resources.

2) Our national land settlement policies gave Western stock ranches a tenure situation which was not conducive to the good stewardship of the lands.

3) Those land policies also gave us a long period of transitional and inadequate-sized units which inclined users to put heavy pressures upon the resource.

4) The low grazing fees and rental rates on the public lands have resulted in heavy use pressures for those lands.

5) During the years of the easily available land credits, in the 1950's and the 1960's, land speculation, the 
buying of ranch properties for development as a tax shelter (prior to the Revenue Act of 1969), and other influences caused Western stock ranches to become over-valued (perhaps very much so, in terms of productivity); the inevitable tendency of this is to put additional use pressures on what has often been an overused or mismanaged resource.

6) The recent flurry of the buying of ranches for subdivision and speculative sale of land tracts appears to be very much on the minus side of the ledger, as far as resource management is concerned.

On the plus side of the ledger, here, as I see them, arc the principal economic influences toward improved use and management of the Western rangeland resources:

1) We now have much better equipment for development and management "know how," and the economic implications of these are better understood.

2) The unit size of the ranches has become more economically possible, and stronger.

3) We shall now probably have a price and earnings situation which should result in much better maintenance and renewal of the land resources.

4) "Gentleman ranching" and other "outside" ranching investments usually have the favorable aspect of being able to accept lower rates of return, when necessary, on the land investments.

5) Mechanization of certain ranching operations has contributed to resource development and improvement.

In assessing these plus and minus factors in the economics of Western rangeland use and management, we must remember that most if not all of the Western rangeland have some watershed values and other long-range public interest values. Water is the lifeblood of the arid West, and the development and management of the range and forest lands of the arid West will do much to determine whether surface waters come from the watersheds unseasonally and in the silt-laden floods that are choking the large-river reservoirs, or whether these waters will recharge the ground water basins and yield their normal potential of quality waters into the streams for storage or for diversion.

This watershed value of the Western range and forest lands often is so overwhelming as to dwarf the value of the rangelands for foragc yield or for maximum short-run livestock production. We do not as yet have very good information about where and to what extent the watershed values and the rangeland production values coincide or are compatible. We must learn this soon, and when we obtain this all-important information we must act accordingly in the management of the public lands, in the public cooperative assistance programs for the privately-owned rangeland, and in the cducational programs and efforts in good rangeland usage. In such programs we cannot, however, assume that ranch enterprise economics will give the needed results, either in the protection of the watershed values, or even in the maximization of the forage yields of the rangclands for the production of livestock. There is too much evidence to the contrary in this, and we need to know where, how, and to what extent we must plan for needed controls, public acquisition, or changes in the size and direction of the cooperative assistance programs for the private lands. We may find that the alternative to expanding deserts and loss of reservoir storage is much more "socialization" than we now have, and that the longer this is delayed the higher the cost.

We were facing a test of wisdom and resourcefulness 40 years ago, and we still do face such a test, now more than ever. Time is about to run out on us, not just on the conserving of a considerable percentage of the Western range resource (the loss of some of which might not in itself be a crucial matter in our total national economics), but for the saving of the watershed functions and values upon which rest the total economy and values of the arid West.

We need a coordinated national plan for the economic development management and conservation of the Western rangeland resource.

The last chapter of the "green book" (The Western Range, Senate Document No. 199, 74th Congress, 2d. Session), is entitled "Program." This chapter reviews the ongoing programs and policies deemed pertinent to progress in the use and management of the Western range resource. Recommendations are then made for changes in those programs and for the development of the new programs believed to be helpful in attaining the objectives set forth in the previous chapters.

Since the publication of this book, in 1936, there have been both progress and retrogression in the condition and trends of the Western range resource. The national programs for the development and management of this resource have undergone changes in direction and emphasis, and perhaps it can be said that in some situations the programs have lost direction and momentum.

As a consequence there is now the need for a completely new look at the situation by a consortium of the interested agencies and institutions, federal, state, and private. The objectives in this should include needed policy guides, revisions of the ongoing programs, and, most importantly, the procedures for achieving the coordination of all of the policies and programs: research, administration of the public lands, education, and the public cooperative assistance programs to ranch enterprise.

It is my view that the economic aspects of rangeland resource conservation and management have been pretty much ovcrlooked in the past programs. If this be true, it is now doubly important that considerable attention be given to this. During the past three decades a whole new set of economic forces and trends have developed in Western stock ranching and range resource usage. Much of what can be done to make the programs more effective will have to be based upon a much better understanding of the economic and social forces and trends.

Probably the work that is needed should be done by a select committee commissioned by the Congress. The makeup of the committee should be clearly specified by the enabling congressional resolution, and the resolution should state clearly the purposes and objectives of the commission.

The principal objectives of such a commission should, as I see them, be:

1) A re-inventorying of the Western rangeland resource condition and trends for each of the major natural regions and principal rangeland types and an analysis of the major factors involved in the problem trends.

2) A review and evaluation of the principal ongoing programs in rangeland resource conservation and management: (a) public lands administration and management; (b) rese a r ch-management and developmental, economic and social; (c) education; and (d) cooperative public assistance for private lands.

3) The formulation of recommendations-concerning policies and policy guidelines, for modification of the ongoing programs, for new enabling legislation, and concerning needs and methods in program coordination.

The Western rangelands, with their arid climates and usually undeveloped soils, have of necessity had an 
extensive type of usage. Because of the nature of the lands and their uses, we cannot expect that range management science can accomplish for Western stock ranching the far-reaching results that agronomic science and soil science have given us in the economic development of tilled-crop agriculture.

However that may be, the Western range resource is extremely important in the fabric of Western economy, and therefore in the national economy.
The challenge is there-a great challenge-for range science and range management to make some great contributions in the future wise use of this immense resource. 